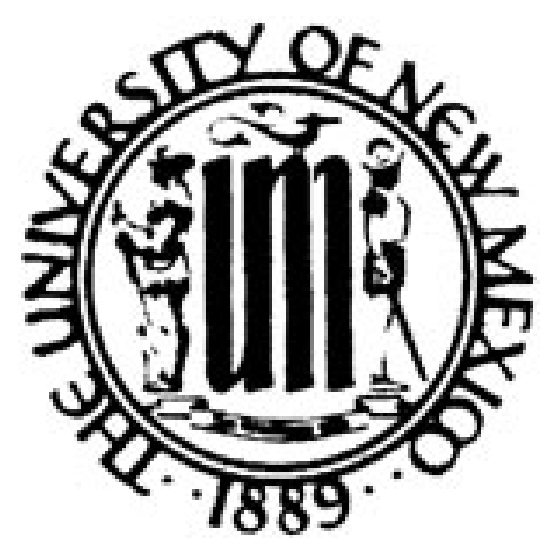

In the Name of Culture: Cultural Relativism and the Abuse of the Individual Author(s): Elizabeth M. Zechenter

Source: Journal of Anthropological Research, Vol. 53, No. 3, Universal Human Rights versus Cultural Relativity (Autumn, 1997), pp. 319-347

Published by: University of New Mexico

Stable URL: http://www.jstor.org/stable/3630957

Accessed: 09/01/2011 11:54

Your use of the JSTOR archive indicates your acceptance of JSTOR's Terms and Conditions of Use, available at http://www.jstor.org/page/info/about/policies/terms.jsp. JSTOR's Terms and Conditions of Use provides, in part, that unless you have obtained prior permission, you may not download an entire issue of a journal or multiple copies of articles, and you may use content in the JSTOR archive only for your personal, non-commercial use.

Please contact the publisher regarding any further use of this work. Publisher contact information may be obtained at http://www.jstor.org/action/showPublisher?publisherCode=unm.

Each copy of any part of a JSTOR transmission must contain the same copyright notice that appears on the screen or printed page of such transmission.

JSTOR is a not-for-profit service that helps scholars, researchers, and students discover, use, and build upon a wide range of content in a trusted digital archive. We use information technology and tools to increase productivity and facilitate new forms of scholarship. For more information about JSTOR, please contact support@ jstor.org.

University of New Mexico is collaborating with JSTOR to digitize, preserve and extend access to Journal of Anthropological Research. 


\title{
IN THE NAME OF CULTURE: CULTURAL RELATIVISM AND THE ABUSE OF THE INDIVIDUAL
}

\author{
Elizabeth M. Zechenter \\ Morgan, Lewis \& Bockius, LLP, Counselors at Law, 2000 One Logan Square, \\ Philadelphia, PA 19103
}

The modern system of international human rights treaties is based on the concept of universalism which holds that there is an underlying human unity which entitles all individuals, regardless of their cultural or regional antecedents, to certain basic minimal rights, known as human rights. The influence of cultural relativism, multiculturalism, and postmodernism is slowly undermining these ideals. Many agree that universal human rights norms simply do not conform with the extreme diversity of cultural and religious practices found around the world and that universal rights should be modified to conform with local cultural and religious norms. Others question the theoretical validity and intellectual coherence of universalism. This is an important debate, the outcome of which will have practical consequences for millions of people around the world. This article examines the concepts of cultural relativism and universalism, their theoretical strength, their social and ethical usefulness, and their intellectual coherence, especially as they influence international responses to gender-based abuses perpetrated against women and other disenfranchised individuals living in non-Western societies.

I am human and nothing human is alien to me.

Terence, 163 B.c.

My own group aside, everything human is alien to me.

Renato Rosaldo, 1984

UNTIL THE SECOND WORLD WAR, the protection of human rights of individuals was seen as a sovereign prerogative of the state and therefore as a domestic rather than an international concern. The atrocities of the Second World War provided the impetus to change that status quo. In the discussion that ensued, most scholars and politicians agreed that individuals are far too vulnerable if left at the mercy of domestic legal systems and that individuals need more protection against abuses suffered at the hand of the state. This agreement was most fully expressed in the creation of the United Nations and the enactment of the complex international regime of universal human rights. This new international legal regime was grounded as much in the empirical evidence of widespread abuses as in the following ethical and philosophical beliefs: (1) no state can be entrusted with an absolute power over its own citizens because of the tendency of states to abuse absolute power; (2) an international regime of human rights protection is needed to protect individuals against states and other supralevel organizations; (3) all individuals are entitled, by virtue of their common humanity, to a basic modicum of human dignity; (4) certain human rights are universal, fundamental, and inalienable, and thus they cannot and should not be overridden by cultural and religious 
traditions; and (5) the accident of birth into a particular social group or culture is not an ethically relevant circumstance and thus has no bearing on that individual's intrinsic human worth and her or his entitlement to be treated as a human being (Buergenthal 1988; Donnelly 1989). The modern system of international human rights treaties-which have been ratified by all nationsreflects these universalist notions. For example, the Charter of the United Nations reaffirms a "faith in fundamental human rights, in the dignity and worth of the human person, in the equal rights of men and women" (United Nations Charter, Preamble, 1945) and states that the goal of the United Nations is to promote universal respect for and observance of human rights and fundamental freedoms for all without distinctions of race, sex, language, or religion (United Nations Charter, Articles 1(3) and 55). Both UN Covenantsthe International Covenant on Economic, Social and Cultural Rights and the International Covenant on Civil and Political Rights-state that "equal and inalienable rights of all members of the human family [are] the foundation of freedom, justice and peace in the world" and proclaim that human rights have their origin in the "inherent dignity of the human person" (CP Covenant, Preamble, 1976; ESC Covenant, Preamble, 1976).

Universalism, thus, is at the root of modern human rights law. Simply put, universalism holds that there is an underlying human unity which entitles all individuals, regardless of their cultural or regional antecedents, to certain basic minimal rights, known as human rights. Traditionally, universalists have based their support for universal human rights on three major jurisprudential theories - the natural law theory, the theory of rationalism, and the theory of positivism (Dworkin 1978). More recently, other theories such as, for example, the human capabilities theory have been proposed to provide philosophical foundations for the universality of human rights (Nussbaum 1993; Sen 1993; Rawls 1971).

Natural law has its roots in the ancient Stoic philosophy but was more fully developed by Thomas Aquinas. The natural law theory emphasizes ethical dimensions of the law. It asserts that individuals have certain inalienable rights of the highest order granted to all individuals by God or Providence and that human-made laws are just only insofar as they do not conflict with the eternal natural laws governing the universe (Weinreb 1987). The natural law philosophy is well illustrated in Antigone, a classical Greek tragedy by Sophocles. When Antigone was prevented by the local polis law from burying her brother, she did so anyway, claiming that her actions were in accordance with a higher, albeit unwritten, law and that this unwritten natural law superseded the man-made polis law. Unfortunately, it is difficult to justify universal human rights based on the natural law theory in a world with a profound cultural and religious diversity, with little, if any, agreement among major cultures and religions about the very existence of a higher order law and its mandates, and in a world plagued by doubts about the existence of any universal moral or ethical norms.

Rationalism, a closely related concept, is a theory of universal laws based on a belief in the universal human capacity to reason and think rationally 
(Donnelly 1989). Rationalism replaces the divine origins of universal human rights found in the natural law theory with the idea that human rights are held by each human being, in an individual capacity, due to the universal capacity of all humans to think rationally. Both rationalism and natural law theory are often combined in the modern human rights discourse and take the form of claims that universal human rights exist independent of culture, ideology, or value systems. In this view, universal human rights are a class of rights each individual possesses by virtue of being a human. They are the rights of final resort, typically invoked when all else has been tried and has failed, and are therefore moral and ethical rights of the highest order. They are also extracultural and are meant to challenge and change the existing norms, practices, and institutions and to subvert oppressive customs (Donnelly 1989, 1990). Both rationalism and natural law ideals are expressed in the American Declaration of Independence, which proclaims: "[w]e hold these truths to be selfevident, that all men are created equal, that they are endowed by their Creator with certain unalienable Rights, among these are Life, Liberty and the Pursuit of Happiness" (Declaration of Independence, para. 1 U.S. 1776). Various schools of thought, including cultural relativism, deconstructionism, interpretivism, and postmodernism, dispute the validity of the rationalist approach by arguing that rationalism is merely a reflection of Western culture and it therefore fails to reflect the diversity of human experience.

Positivism, on the other hand, justifies the existence of universal human rights by noting the worldwide acceptance and ratification of human rights instruments. According to positivists, universal human rights norms have been created by and are embodied in the international treaties and customary international law (Higgins 1994). Positivists observe that cultural differences notwithstanding, all Western and non-Western nations have signed and ratified the vast majority of human rights treaties and agreements, a fact which attests to the worldwide acceptance of the human rights principles set forth in these treaties and agreements. This uniform worldwide acceptance provides, therefore, a legitimate basis for adherence to such universal human rights and other standards underlying these treaties and agreements. Positivists also observe that the source of human rights lies not in individual cultures but rather in international law which gave rise to the idea of universal rights. Consequently, positivists claim that human rights cannot be withdrawn by any domestic legal system and must take priority over the conflicting norms of different domestic systems. Although positivism provides a sound legal justification for universality of human rights, it does so primarily for individuals living in modern nation-states. Unfortunately, positivism fails to justify universal rights for indigenous peoples, many of whom were forcefully annexed into modern states and many of whom deny that modern states have a moral or legal authority to represent them in the international arena.

The capabilities theory and related approaches look at the quality of life of various groups and individuals and ask whether individuals in a given culture live as decent a life as they are capable of living (Sen 1993). This approach 
focuses on the question of what it means to be human. It evaluates various subgroups within the society and compares them against each other in order to detect structural inequalities. The capabilities theorists look for commonalities among cultures, religions, and philosophical traditions, as well as commonalities among men and women, and use those commonalities to argue that all individuals must have at least some minimum rights necessary for human functioning (Nussbaum 1993). Although the capabilities theory represents a very thoughtful attempt at justifying universal human rights, its primary weakness lies in its failure to adequately account for the fact that certain significant differences among cultures just cannot be reconciled by looking for commonalities or points of agreements among these cultures.

Since most attempts to provide solid philosophical foundations for the universality of human rights have not been entirely successful, the universal foundations of international human rights are subject to numerous empirical and theoretical attacks, primarily from the various proponents of cultural relativism. Until recently, the international legal community has uniformly subscribed to the view that human rights should be universal and that the international human rights regime created by the United Nations, as well as by other regional human rights systems, should be enforced evenhandedly, irrespective of differences in cultural customs and religions. If human rights were to have different meaning to Western and non-Western countries, the whole system of human rights law would be rendered meaningless. Consequently, the international community has shown reluctance to defer to "culture" in cases of conflict between international human rights and cultural values. In fact, international human rights law mandates that the states must combat culture-based violence, especially if such violence is being disguised as a religious or a cultural practice (United Nations Human Rights Commission 1989). The current international law embodies, therefore, a collective affirmation by the world community of the fundamental unity of the human race.

Although the universality of human rights is still widely accepted by many nations, the influence of cultural relativism and multiculturalist and postmodernist ideas is slowly undermining the entire system of international human rights treaties (Sullivan 1994). This growing debate about the validity of the universalist assumptions underlying the human rights regime is, to some degree, inevitable in a world with ever-increasing interconnectedness and globalization. Human rights institutions are increasingly exposed to a growing variety of norms, values, and beliefs, and to competing claims of legitimacy from various cultures and subcultures. To human rights relativists, universal human rights norms are impossible to defend in such a richly diverse world and are no more than a "Western concept with limited applicability" (Pollis and Schwab 1979:1). Armed with relativist arguments, numerous groups have mounted formidable challenges to the ideal of universal human rights, including such constituencies as (1) Asian and Islamic governments which, despite their ratification of all major international human rights instruments, outrightly reject human rights universalism, particularly as it pertains to hu- 
man rights of women living in their jurisdictions; (2) numerous Third World regimes which wish to avoid intense international scrutiny of the domestic treatment of their citizens; (3) representatives of the newly organized indigenous groups who crave legitimacy for themselves and their cultures; (4) many social scientists and philosophers engaged in a search for sounder theoretical justification of human rights universalism and its principles; (5) persons who value human "diversity" and who view human rights as an extension of the Western sphere of influence; and (6) those who fear that human rights universalism encourages uncalled-for interference with other cultures. Most of the above-mentioned groups or individuals argue that the promulgation of universal human rights laws simply does not conform with the extreme diversity of cultural and religious practices found around the world and that universal rights should be subsidiary to local cultural and religious norms. Others question the theoretical validity and intellectual coherence of various theories underlying international human rights law. Clearly, this is an important debate, the outcome of which will have practical consequences for millions of people around the world.

This article examines the applicability of cultural relativism to the international human rights regime, especially as it shapes the international responses to gender-based abuses perpetrated against women and other disenfranchised individuals living in non-Western societies. The first part briefly outlines various formulations of cultural relativism. The second part focuses on major theoretical and practical weaknesses of cultural relativism as applied to the human rights arena. It argues that the culture-relativist critique of the modern human rights law is largely invalid and has corrupting effects on the human rights regime, and it concludes that human rights universalism, despite all its flaws, is still the better approach.

\section{CULTURAL RELATIVISM AS A SOCIAL SCIENCE THEORY}

\section{Variants of Cultural Relativism}

Cultural relativism gained prominence in the second part of the twentieth century and is considered by many to be a hallmark of modern anthropological and social scientific thought (Bidney 1968). Stated briefly, cultural relativism is a theory which asserts that there is no absolute truth, be it ethical, moral, or cultural, and that there is no meaningful way to judge different cultures because all judgments are ethnocentric (Gellner 1985). In practice, it is rather meaningless to speak of the theory of cultural relativism today, since there are several different variants of the theory, ranging from descriptive relativism (also known as weak relativism; amounting to a commonsense observation that cultures vary), through normative relativism (or strong relativism; positing that since all standards are culture-bound, there can be no transcultural moral or ethical standards), up to the most extreme form of relativism, known as epistemological relativism (or extreme relativism), exemplified by Geertz and his followers (claiming that humans are shaped exclusively by their culture and therefore there exist no unifying cross-cultural human characteristics) (Jarvie 1983; Spiro 1984, 1986). 
The early form of cultural relativism was a reaction to the ethnocentric assumptions of nineteenth-century science which glorified Western societies and diminished the achievements of non-Western cultures. Nineteenth-century scientists saw human evolution as a process of progressive change from the primitive to the advanced (Spencer 1904). Although they understood, more or less correctly, the basic scheme of socioeconomic evolution of human societies (which $i s$, in fact, characterized by the gradual change from foraging to adoption of agriculture and the emergence of chiefdoms and states), they erroneously incorporated extraneous value judgments into that scheme. Descriptive relativists became skeptical of broad generalizations about human beings and challenged the notion of the natural superiority of Western civilization (Boas 1894, 1901; Benedict 1934; Mead 1928, 1963). Instead they emphasized the seemingly endless human diversity and were able to demonstrate that even cultures placed at the bottom of the evolutionary scale were advanced and sophisticated at least in some aspects of their cultural development. In fact, descriptive relativists focused so much on exposing seemingly vast cultural differences, they tended to disregard data showing a significant degree of patterned similarities among human cultures (Edgerton 1992).

Normative relativists were convinced that in addition to being highly variable, cultures inculcated their members with moral and ethical rules through involuntary socialization and enculturation and that few, if any, individuals were consciously aware of the arbitrary character of beliefs that were ingrained into them (Herskovits 1958, 1973; Fernandez 1990). Consequently, normative relativists felt that there could be no extracultural standards by which other cultures can be judged, thus forcing relativists to accept and tolerate all practices engaged by others. Benedict observed, for example, that morality "differs in every society, and is a convenient term of socially approved rights"; consequently she viewed all cultures as "equally valid patterns of life" (Benedict 1934:278).

This formulation of relativism has been characterized by some scholars as "intellectually irresponsible." Kluckhohn, for example, observed that ethical relativism is flawed because "if one follows out literally or logically the implications of Benedict's words, one is compelled to accept any cultural pattern as vindicated precisely by its cultural status: slavery, cannibalism, Nazism, or Communism may not be congenial to Christians or to contemporary Western societies, but moral criticism of the cultural patterns of other people is precluded" (Kluckhohn 1955:266). Despite the criticism, relativists argue that as a practical matter relativism must be coupled with absolute tolerance of other cultures or it would lose its teeth. Consequently, they believe that any attempt to make cross-cultural judgments or to create universal standards renders relativism ineffective or trivial (Hatch 1973, 1983). Furthermore, many anthropologists prefer to avoid judgments altogether because they fear that criticism of other cultures and practices could become a theoretical and political minefield for the discipline (Downing and Kushner 1988). Some believe that anthropology must be objective and ethically neutral in order to be scientific and conclude that true 
scholarship is incompatible with any form of evaluation (Steward 1948; Hastrup and Elsass 1990). Others feel that criticism of any cultural practice, no matter how inhumane, would jeopardize their fieldwork and academic careers (Downing 1988). To be sure, anthropologists doing fieldwork are often faced with an ethical conflict when they observe culture-sanctioned abuses of individuals. If anthropologists choose to support an indigenous society in its struggle against human rights abuses propagated by an oppressive state or some other large multinational entity, state officials may retaliate against the whistle-blowers and deny permission to conduct fieldwork. If anthropologists choose to support a state policy aimed at eradicating human rights abuses perpetrated by an indigenous society against its own members, that society may refuse to cooperate with anthropologists, thus making fieldwork difficult or impossible. Finally, if anthropologists decide to help a dissenting individual or group which rebels against dehumanizing customs of its own culture, lack of cooperation from that society may make the fieldwork equally impossible. Given the high cost of fieldwork and the large empirical, theoretical, and financial investment that goes into field projects, few anthropologists have been eager to get involved in human rights issues. Many anthropologists.willingly, if somewhat unconsciously, embrace the self-serving illusion of neutrality and objectivity to resolve the moral dissonance caused by observing injustice and take solace in leaving the balance of power unaltered by their presence in the societies they study. However, as John Stuart Mill observed, "a person may cause evil to others not only by his actions but by his inaction, and in either case he is justly accountable to them for the injury" (Mill 1952[1859]:272).

In the 1970s the most radical version of cultural relativism, known as epistemological relativism, emerged. Epistemological relativists argued that not only do there exist no extracultural standards against which cultural practices may be judged as acceptable or unacceptable because all cultures are mutually incomprehensible-as Rosaldo put it, "my own group aside, everything human is alien to me" (Rosaldo 1984:188) - they also argued that there is no such thing as objective reality, truth, or reason (Geertz 1973, 1984; Clifford and Marcus 1986; Marcus and Fisher 1986). According to epistemological relativists, all knowledge and morality are exclusively culture-bound, and rational thinking and the scientific method are no more than a culturally bound form of Western ethnoscience. In that view, science is not a logically coherent system of verification and falsification, but rather a culturally biased way of thinking that is no different from magic or witchcraft (Geertz 1973, 1984). The rise of epistemological relativism coincided with the emergence of many new schools of thought that rose to prominence at that time such as deconstructionism, postmodernism, and Marxism, all of which have attacked the very idea of scientific, rational, or ethical reasoning. Marxism, for example, emphasizes the inevitability of class consciousness in shaping individuals' viewpoints (Kolakowski 1978). Deconstructionism and postmodernism profess that there is no way of knowing anything beyond one's direct experience and reject the very concept of reality (Jameson 1991). All these schools repudiate the con- 
cept of objectivity and consequently the universality of basic human rights. To many anthropologists steeped in those theories, any attempt to define even the most basic scheme of universal human rights is meaningless $a b$ initio.

As a result of the confluence of the theoretical and pragmatic concerns described above, many of which are indeed valid, anthropology as a discipline has largely failed to examine culture- and group-sanctioned abuses of individual human beings (American Anthropological Association Executive Board 1947; Messer, this issue). Moreover, by adopting cultural relativism, proclaiming unqualified tolerance of all cultures, and by taking a group-centered perspective, anthropology has left little room for rational discussion about the rights of individuals, particularly in non-Western societies.

\section{Reactions against Cultural Relativism}

Obviously not all anthropologists accept cultural relativism and the antiexplanatory and antiscientific particularism of its variants. Many reject relativism in favor of an evolutionary analysis by observing that societies do indeed change their customs by developing more humane habits in conjunction with the growth of their economic, technological, and scientific capabilities. They emphasize the common denominators among cultures, suggesting that it is proper to speak of the common humanity of people as the basis for cross-cultural morality and ethics that are not completely culturally relative. Redfield $(1953,1957)$ and Kroeber $(1935,1948,1952)$, for example, have tried to develop an objective scheme by which one could judge other cultures' customs. Kroeber $(1948,1952)$ suggested that there is an observable progress from nonstratified to stratified cultures. He saw cultural evolution as an increase in technological traits accompanied by increased rationalism and a corresponding decline in magic, superstition, torture, mutilations, and other religiously motivated brutalities.

In the 1960s, Sahlins (1960) demonstrated that cultural evolution is more usefully viewed as a combination of two simultaneous processes of specific and general evolution. Specific evolution involves adaptation to various ecological conditions, whereas general evolution is progressive insofar as more complex forms replace simpler ones. Sahlins observed that specific and general evolution are not different realities, but rather aspects of the same process. Specific evolution accounts for local variations in ecology and accidents of history; thus it lends itself to the relativist point of view. General evolution, however, is a progressive change that allows us to make comparisons, to rank various cultures, and actually to demonstrate cultural progress. According to Sahlins, general evolution is characterized by the increased ability of cultures to harness energy; increased complexity in social organizations from simple foraging bands, through tribes, chiefdoms, and finally to states; and the greater year-round adaptability to physical environment. There is a wealth of archaeological and ethnographic data that confirms beyond doubt the basic evolutionary character of human culture (Flannery 1972; Sanders, Parsons, and Santley 1979; A. Johnson and Earle 1987; Service 1975; Steward 1955). Reflecting a 
major departure from Spencerian evolutionism, modern anthropology views evolution as change caused by a combination of mounting population pressure, greater intercultural contact, and increasing technological development, rather than simply as progress. In fact, evolutionary change is costly, and its benefits, such as increased food security, increased protection from predators, and growth in scientific and medicinal knowledge, are often counterbalanced, although not entirely offset, by the costs of evolution, which include increased labor costs, increased work time, declining marginal productivity, increased warfare, and the decline of individual liberty for all, especially for women, that accompany the emergence of social stratification (Boserup 1965; Cohen 1977; A. Johnson and Earle 1987).

Feminist scholars are also deeply troubled by the fact that relativism, postmodernism, or deconstructionism marginalize gender-based violence and avoid the reality of systemic power imbalances between the sexes (Gordon 1993; Moore 1988). Moreover, they are concerned that large numbers of nondominant groups and individuals from various societies are routinely disregarded and excluded from cultural relativists' analyses as if they merited no attention.

Others, like Gellner (1985), question the cultural relativist assertion about the inherent incomparability of different cultures by observing that although numerous social scientists have conducted fieldwork in seemingly alien cultures, and numerous individuals have traveled and lived in alien cultures, no one has ever encountered a culture that was so vastly different as to be wholly incomprehensible or uninterpretable to outsiders. Similarly, no language has ever been found that was not capable of being understood, translated, and acquired by outsiders. In fact, modern research indicates that language acquisition is largely genetically controlled (Pinker 1994). Moreover, the fact that numerous individuals have been able successfully to switch cultures, migrate into other cultures, or adopt or modify their own customs and beliefs belies the idea that humans are so exclusively shaped by their native culture as to be incapable of comprehending or adopting other cultures or that cultures vary so significantly as to be entirely unintelligible to outsiders. Gellner's insights have been strengthened by modern research in evolutionary psychology, sociobiology, primatology, psychiatry, modern cognitive sciences, and neurosciences, which shows rather convincingly that there is such a thing as universal human nature, lending credence to the universalist belief that there is an underlying human unity which allows us to devise minimum universal standards applicable to all human beings regardless of their culture (Barkow, Cosmides, and Tooby 1992; Tooby and Cosmides 1990; Daly and Wilson 1983, 1988).

\section{WHAT IS WRONG WITH RELATIVISM IN THE AREA OF HUMAN RIGHTS?}

Cultural relativism has many flaws. Most formulations of it are contradictory; others are tautological. As a whole, relativism is based on a static conception of culture. It shows a bias toward functionalism and tends to justify 
the dysfunctional beliefs and customs of non-Western cultures while marginalizing nondominant voices within those societies. It overemphasizes the rights of a group over the rights of individuals. It forces us to abandon any meaningful discussion about other cultures. However, the most troubling aspect of cultural relativism is its application to the international human rights legal regime because of its potential consequences. At a minimum, if relativism were to undermine the universalist foundations of modern international human rights law, all meaningful dialogue about human rights abuses would end. Instead, all sorts of culturally sanctioned violations of individuals would be legitimized, and individuals would be left unprotected against rulers, governments, and others in power. Before taking up the argument in favor of human rights universalism, let us consider two real-life cases and use them as a springboard for our analysis.

\section{Case I: Indian Sati}

In 1987, Roop Kanwar, an eighteen-year-old Rajput girl, was burned alive on her husband's funeral pyre. She was married by her parents through an arranged marriage at the age of sixteen and was a university student when her husband died of cancer. It is not clear whether she committed sati voluntarily or under pressure from her in-laws. It is said that she appeared to be heavily drugged on the day of her burning. The case caused quite a stir in India. Women's groups organized marches in protest of the practice. Many of the Rajputs, however, both men and women, defended the practice on the basis of cultural relativism stating that sati is an ancient Rajput tradition. They claimed the right to commit sati as part of their ethnic culture and erected a shrine in honor of Roop Kanwar, who became a symbol for a group of Rajput extremists. Indian human rights activists were branded by them as Western imperialists imposing their views on ancient Indian culture. The Indian feminist movement was discredited for denigrating their national culture, for its lack of national pride, and for tarnishing the image of India abroad. Although the Indian government has repeatedly passed laws prohibiting sati, these laws are difficult to enforce because federal prosecutors are often unable to gather evidence against the offenders from a community that protects them. (extracted from Coomaraswamy 1994:39-57)

Consider a few hypothetical questions:

Would it matter and should it matter whether Roop Kanwar committed sati willingly? Would it be justifiable cultural practice if she committed sati voluntarily?

Would it matter if she objected to her death? Does she have the right to reject the cultural practices of her culture or her ethnic subgroup, or is she bound, through the accident of her birth, by these practices no matter how unfair they are? 
Would sati be justifiable if it were supported by a majority of a group? Would justifications of sati hold the same legitimacy if the vast majority of sati supporters were men while 100 percent of the victims were women? Is it relevant that there never was a sati burning in which the victim was a widowed man and that most supporters of sati find the idea of male sati totally ridiculous?

What if sati supporters were political opportunists using sati as a way to rally political support and to divide the Indian society along ethnic subgroups?

What if women who support sati were mothers-in-law of sati victims? Does it matter that given the land inheritance system in India, a widowed woman has a legal right to inherit her deceased husband's land? Does it matter that the in-laws of a widowed woman have a significant economic incentive to dispose of her in order to retain ownership of the land, which is their primary, if not only, asset? Is an invocation of an ancient custom sufficient to legitimize the practice?

Does the age of a sati victim matter? What if she is fully controlled by the family of her in-laws? What if she is a child? What if she is an older woman who has already lived most of her life and is considered an economic burden on her children? Does it matter whether the woman is pregnant or not? How far along does she have to be in her pregnancy before her death by sati would be unjustified? And if a pregnant woman is to be spared, does she become eligible for sati after the childbirth?

Is sati legitimate if the woman consents to her own burning? Can her consent ever be legitimate? Can her consent ever be informed? If she lived her whole life in a small village and knew of no other role models for women, would she be considered capable of rendering an informed and voluntary consent?

Is it relevant whether the sati victim is a child bride, through an arranged marriage, living since her early puberty in her in-laws' house with no income or decision-making power of her own? Is it relevant whether she has any practical options other than "voluntary" death by sati? Does it matter that if she were to refuse to die, she would be ostracized by the village, her in-laws would throw her out of the house, and she would have no place to go?

Is it wrong for Indian feminists and human rights activists to invoke the universal human rights ideals in their fight against sati and other practices of torture or violence against Indian women? Are these Indian feminists betraying their national heritage by doing so? Are these Indian feminists and Indian human rights activists mindless victims of Western cultural imperialism? Is their judgment of Indian cultural heritage less legitimate than that of the supporters of sati?

What of the long-standing, pluralistic, and rationalistic traditions of India which are similar to those espoused by Western universalism (Nussbaum and Sen 1989)? Do these traditions, considerably older than the advent of sati in Rajasthan, provide the needed cultural legitimacy to the position of Indian feminists and human rights activists?

To most rational people familiar with the facts of Roop Kanwar's case, whether they live in India or abroad, no doctrine or philosophical theory, in- 
cluding cultural relativism, is sufficient to justify her death. Cultural relativism, no matter how nuanced, inevitably provides the logical justification for such inhumane practices. Ironically, the cultural-relativist defense of sati has the detrimental effect of disregarding the well-demonstrated plurality and diversity of Indian traditions in favor of adopting one view as representative of Indian culture, in this case the view of sati supporters. Such a cultural-relativist construction of Indian customs and traditions merely serves those who pick and choose ancient customs at will and those who resurrect customs to serve their own political agenda (in this case, Rajput extremists) or their own economic needs (in this case, Roop Kanwar's in-laws).

\section{Case II: Algerian Holy Warriors}

In 1996, two teenage Algerian girls were first raped and then murdered in front of the entire village by the followers of fundamentalist Islamic leader Sherif Kosami, who issued an edict that all women who attend schools, in violation of the tradition of Islam, shall be raped and murdered. In addition, the mother of the two girls was slaughtered when she attempted to shield her daughters. The murdered girls were fifteen and sixteen years old and attended high school in the hope of becoming either nurses or doctors. Both were religious, both wore veils, and both studied the Koran daily. According to the girls' father, the girls wanted to practice medicine in small villages where there are no women doctors and where village women are deprived of basic medical help because Islam prohibits women from undressing in front of male doctors. Sherif Kosami, religious leader of the fundamentalist Armed Islamic Group, does not approve of women's education because, in his view, education corrupts Muslim girls. Kosami has issued an edict in which he proclaims that women attending schools should be punished by death. Moreover, Kosami believes that the "holy warriors" of Allah, i.e., his followers, have a moral and religious right to rape their victims, or as Kosami puts it, they have a license "for enjoyment of marriage." The newspapers report that at least 112 schoolgirls or women teachers were raped and murdered in Algeria in the first few months of 1996. (extracted from Bhatia 1996:C11)

Again, consider a few question in this case:

Does it matter that both parents of the slain girls believed that education was appropriate and necessary for their Muslim daughters? Are their views as legitimate as those of Kosami? And if yes, why is it that many cultural relativists would argue that Kosami's actions are culturally sanctioned? Correspondingly, why are the less popular views in a culture not considered to be worthy of protection?

What if Kosami and his policies were overwhelmingly supported by Algerian women? What if many Muslim women have so deeply internalized the 
inferior status afforded to them by Muslim clerics that they frequently endorse their second-class status as natural and a part of the God-given order of things? How should the international community deal with this situation?

Can an individual espouse ideas that are outside the mainstream of her culture or embrace novel ideas in order to change the native culture? If not, how could any culture ever change? Does the job of deciding whether an idea or practice is typical of a culture (and, therefore, blessed as legitimate by cultural relativists) always rest with the group? Given that various groups and individuals within Algeria hold different views as to what constitutes Islamic or Algerian culture, what are the criteria for deciding which subgroup actually represents the true Algerian culture? Whose viewpoint shall the international community accept as legitimate and why?

Why shouldn't the international community insist that all cultures, no matter what their beliefs, be bound by universal human rights that prohibit torture and murder? Is it not, in fact, better that instead of engaging in judgments as to which subgroup represents the true culture, we guarantee instead certain minimum rights, such as the right to life, to all individuals in every culture, as the international human rights law currently does, so that individuals can decide for themselves to which subgroup they wish to belong and to which beliefs they wish to subscribe?

In thinking about these issues, let us keep the following facts in mind. A typical ratio of males to females at birth ranges between 106:100 to 104:100 (Sen 1990). In contrast, Islamic countries have the lowest ratios of females to males in the world, dipping as low as 48:100 in the United Arab Emirates, 60:100 in Qatar, and 84:100 in Saudi Arabia (Nussbaum 1995:90). Sen has calculated that as many as one hundred million women worldwide are currently "missing" and that a "great many more than a hundred million women are simply not there because women are neglected compared to men" and therefore are not given medical care or nutrition comparable to their male counterparts (Sen 1990:66). In many traditional cultures, disproportionately fewer female children survive childhood, and the survivors disproportionately suffer from malnutrition, diseases, and beatings and are routinely refused medical care and education resulting in women having a significantly lower life expectancy than women in other cultures. Given these facts, which demonstrate a long history of abysmal treatment of women living in traditional societies, any invocation of tradition to justify brutalities against women must be treated with a great deal of skepticism and be subjected to the highest level of international scrutiny. The cases of Roop Kanwar and the Algerian girls are, in many ways, "easy" because in both situations, the victims lost their lives in the name of "culture." What about customs that "merely" restrict women to home, or veil them, or mutilate them, or prevent them from obtaining education, or deny them salaried jobs, etc.? Most cultural practices that restrict women are not benign, and many have grave if not outright morbid consequences. Which cultural practices are internationally sanctioned and allowed to exist is therefore a matter of enormous consequence. In the follow- 
ing section, I will try to point out why it is imperative that we retain and uphold the universal nature of human rights law.

\section{Contradictions of Cultural Relativism}

Logical scrutiny reveals that most applications of cultural relativism to human rights are self-contradictory. On the one hand, relativists subscribe to the proposition that there are no universal laws or principles, yet on the other hand they also insist that one must be tolerant of the cultural practices of others, thus making tolerance a de facto universal principle. If it is true that there are no universal rules, be they ethical or moral, then cultural relativists commit an error by demanding that, as a matter or principle, no cultural practice should ever be judged by other cultures or by outsiders. So long as we recognize at least one universal principle, we should carefully consider which principles deserve to be applied universally and which do not. A good case can be made that other values, such as justice and fundamental fairness, are far more worthy of being promoted as universal rather than the principle of tolerance where tolerance is defined not as avoidance of hasty judgments but rather as an avoidance of any extracultural judgment irrespective of circumstances.

Cultural relativists tend to employ the concept of culture as a ready-made, all-purpose explanation of human behavior. Why did the practice of sati evolve amongst Rajputs? Why did the Rajputs abandon the practice of sati at a certain point in time? Why are some people trying to resurrect it? Cultural relativism offers no meaningful explanations to any of the above questions and prevents us from a rational discussion of any opportunistic uses and misuses of tradition. Appeals to selectively chosen ancient customs or religions should be more properly analyzed as attempts to legitimize the political or religious agendas of various factions within a society. Correspondingly, it is questionable to assume that the views of the individuals opposing traditional practices are somehow inauthentic or not reflective of their culture. These individuals are no less members of their society than various fundamentalists who claim to uphold "the tradition." The father of the slain girls voiced that concern poignantly when he told the reporters, "my daughters died as martyrs. . . . These madmen who took the lives of my wife and daughters are the enemies of Islam" (Bhatia 1996:C11).

\section{Static Conception of Culture}

Cultural relativism is based on a static conception of culture. By emphasizing stability and cultural continuity of customs or traditions, relativism disregards or minimizes the importance of social change. In fact, it ignores the inevitability of change in every society and dismisses the thorny fact that some traditions persist while others are selectively discontinued. All forms of cultural relativism fundamentally fail to recognize culture as an ongoing historic and institutional process where the existence of a given custom does not mean that the custom is either adaptive, optimal, or consented to by a majority of its adherents. Culture is far more effectively characterized as an ongo- 
ing adaptation to a changing environment rather than as a static supraorganic entity. In a changing environment, cultural practices routinely outlive their usefulness, and cultural values change either through internal dialogue within the cultural group or through cross-cultural influences. Any contact between cultures is likely to cause at least some modification in the customs of the contacting cultures or at least to induce a reinterpretation of these customs. It is this constant reinterpretation, reinvention, and modification of customs that allows cultures to survive and be viable over time.

Culture can also be viewed as an uneasy compromise between conflicting needs and wants of various groups and classes within the society, where the dominant group tends to maintain perceptions and interpretations of cultural values and norms that are supportive of its own interests, proclaiming them to be the only valid view of that culture. For example, ethnographic examples indicate that men, who as a group dominate the power structure of most stratified societies, have discarded ancient customs that are inconvenient to them but have selectively retained those customs that tend to subordinate and disadvantage women (Butegwa 1993). Although violence against women has been documented in practically all types of societies, the distribution of such violence and gender-based dominance varies significantly. For example, women living in foraging groups enjoy a high degree of freedom and equality (Lee 1979, 1984; Lee and DeVore 1968; Leacock 1978; Kaplan, Hill, and Hurtado 1990). Similarly, women living in simple horticultural matriarchal societies have a higher degree of participation in their culture and are far better protected against group-based violence than women living in patriarchal groups (O. Johnson 1978). In contrast, women born into stratified societies endure high levels of physical violence, rape, spousal abuse, unequal access to diet, restrictions on movement, and female infanticide (Edgerton 1992). The division of labor is also not equitable in most societies (A. Johnson and Earle 1987). Time allocation studies reveal that women work typically longer hours than men and that this difference is most pronounced in nonegalitarian societies (A. Johnson 1975, 1987). In most stratified societies, women serve as beasts of burden, carry loads of water and firewood, engage in daily subsistence and child-caring activities, and even have been documented to engage in hunting, warfare, and diving for food. Furthermore, nutritional studies show that even if some societies can ensure an adequate diet for all their members, they selectively fail to do so in the case of women and female children, depriving even pregnant or lactating women (P. Johnson 1981). Such failure is maladaptive and has detrimental effects on the longevity and quality of life of such societies (Edgerton 1992). At the same time, in most stratified societies women are excluded from public affairs, and men dominate the social, religious, and political agendas (Edgerton 1992; Sahlins 1968, 1972; Boulware-Miller 1985; Dwyer 1991). In many regions, the low status of women was further reduced at the time of colonization with the imposition of new political, social, and cultural orders (Etienne and Leacock 1980; Leacock 1978). In recent years, this process of marginalization of women was again reinforced by well-mean- 
ing economic programs instituted by multilateral institutions, such as, for example, the structural adjustment programs instituted by the World Bank or the lending practices of the International Monetary Fund (Joint Consultative Group on Policy 1991). By emphasizing stability, cultural relativism disregards and minimizes the systemic aspects of women's subordination, much of which seems to be correlated with the socioeconomic level of development of a given society, rather than being some immutable characteristic of human life.

It is also significant that women from many stratified societies seek to change the restrictive and outdated social customs in order to survive. For example, many Algerians deplore Kosami and his extremist views. Newspapers report that more than a hundred thousand Algerian women demonstrated in 1996 against various religious fundamentalists who want to resort to the most restrictive of traditional Muslim customs in order to gain even greater control of women. As one Algerian woman put it, "Women here are the leaders of change in society. ... Algerian women have a long tradition of fighting so that fundamentalists consider them enemy" (Bhatia 1996:C11). Such actions are often described by their opponents as foreign-motivated implants. A more accurate view would be to recognize that Muslim women are engaged in a socioeconomic and political struggle with religious fundamentalists, who manipulate religious and cultural ideology to their own advantage and who disregard other, more liberal strands of Muslim ideology. Discrediting of indigenous aspirations for social change as nothing more than Western contamination or as an aberrant foreign import, merely because these aspirations run counter to some entrenched cultural practices of the majority in power, seems to show singularly bad judgment.

Instead of using culture as the so-called explanation and justification for all behaviors, it is far more fruitful to analyze (1) whose interests are being served by the "traditional" customs and whose are infringed by them, (2) why some customs are abandoned while others are maintained or resurrected and by whom, (3) who benefits from change in cultural practices versus who gains from maintaining the status quo, (4) who is influencing the direction and the internal dynamics of cultural change and whether such cultural changes might lead to genuine equality and improvement of life to currently marginalized subgroups or individuals or to a further disenfranchisement of the voiceless, and (5) what is the best way in which the universal ideals of human rights could be used to effect change in the nature and dynamics of native power relations in order to produce more equitable results. It would seem only appropriate that the cultural relativists who deride human rights universalism as superficial should bear the burden of enumerating some sort of criteria by which the international community may judge which groups or individuals within a given culture should be classified as legitimate representatives of that culture. Without such criteria, it is impossible to decide what is and what is not part of a given culture and why. The modern international human rights regime, in contrast to the relativistic proposals, represents a thoughtful attempt to balance competing claims for the legitimacy of various groups and societies, while protecting those most at risk. 
Functionalism

Many relativists provide tacit or even explicit justifications of cannibalism, infanticide, genital mutilation, torture, violence, brutality against women and children, torture of animals, and other practices that are repugnant of the ideals of international human rights (Benedict 1934; Edgerton 1992). Harris, the leading proponent of cultural materialism, has long argued that virtually all cultural practices are adaptive, even if the people who engage in them have no conscious understanding of these customs and practices (Harris 1971, 1977, 1985). Anthropological data show, however, that many societies engage in customs and practices that are either inefficient or inhumane or are actually maladaptive in that they endanger human health, happiness, biological, and even cultural survival (Edgerton 1992). In fact, persistence of a given custom does not mean that it is adaptive, optimal, or consented to by a majority of its adherents (Cavalli-Sforza and Feldman 1981; Boyd and Richerson 1985). Boyd and Richerson (1985) have shown that maladaptive practices can spread in a population due to indirect bias even under natural selection and in the presence of better-adapted variants. Consequently, beliefs and practices that are harmful, inefficient, or neutral from the evolutionary point of view can and do persist over long periods of time.

Relativists and functionalists presume that cultures should not be tinkered with, lest they should be irreparably damaged or destroyed. They are concerned that change, whether effected by internal or external factors-such as the universal human rights laws-could lead to destruction of cultures, for if a part of a culture is modified or taken away, then the whole culture might collapse. Consequently, functionalists focus on justifications of traditional customs, forgetting that cultures have been continuously changing and remaking themselves throughout the history of human evolution. It is highly unlikely, for example, that the millennia-old Indian culture will suddenly disappear or be damaged if we were to eliminate brutal practices such as the burning of widows and if we were to insist on the protection of the right to life of women like Roop Kanwar. In fact, India has demonstrated, rather conclusively, that fundamental beliefs can be changed in a relatively rapid manner without a corresponding collapse of society. For example, India has made enormous strides in mitigating the importance of the caste system, a system of beliefs that appears to be far more ingrained in the Indian psyche than the custom of sati ever was. In practice, cultural change is inevitable if cultures are to survive and thrive in the changing world. Blind adherence to old customs that have long outlived their usefulness is nothing but counterproductive. In addition, not all cultural practices are of equal importance in the overall culture of the group, and some can be modified more easily than others. It is erroneous to assume that a reduction in culturally sanctified violence, such as sati, would somehow undermine Indian culture. And yet numerous anthropologists, beholden to cultural relativism, justify the cultural and religious beliefs of other societies, even if those justifications are farfetched and frankly quite unconvincing, rather than examine their rational, ethical, and adaptive qualities (Edgerton 1992). 


\section{The Misconception about the Existence of Traditional Culture}

Cultural relativism admonishes us to respect traditional cultures but tends to gloss over the fact that even in the most egalitarian and nonstratified of societies, there is no such thing as one culture. Instead, all cultures always have consisted of groups and individuals with conflicting agendas, and their customs have reflected the interests of the dominant classes.

It is exceedingly hard to determine how one should go about deciding which customs are representative of a given culture. Shall we, for example, assume that if 100 percent of the individuals within the culture practice a given custom, then such custom is legitimate? Or can we just accept a simple majority's view as to what their typical cultural beliefs and practices are? And what if this majority benefits from the given practice at the expense of the minority? Is such a practice still legitimate and representative of that culture? Judgments as to what are the boundaries of a given culture and what are its representative customs and traditions are inevitable and cannot be avoided just by embracing cultural relativism, although such an avoidance of judgment appears to be one of many reasons that cultural relativism remains so attractive. Given the long-standing history of Western imperialism, many scholars and politicians are appropriately hesitant to judge foreign cultures, lest they stand accused of ethnocentrism and lack of sensibility to others. Considering the enormous difficulty involved in making any judgments, especially wise and balanced judgments, it is easy to understand the reluctance to make them. Although no one can deny that even the best judgments and sound reasoning can be and have been used in an ethnocentric manner, making judgments is not synonymous with ethnocentrism per se. Cultural relativists are correct in pointing out that by endorsing or rejecting a foreign custom, one risks an imposition of one's own cultural prejudices on others. They are also correct in emphasizing that upbringing and education bring with them inherent biases. But the belief that judgments of other cultures must be avoided altogether, because they may be ethnocentric, is illusory. One simply cannot avoid making judgments when faced with oppression and brutality masquerading under the guise of cultural tradition. Such a nonjudgmental tolerance of brutality is actually an ultimate form of ethnocentrism, if not an outright ethical surrender. The fates of Roop Kanwar and the Algerian girls call for moral and ethical decision making. By withholding judgment in either situation, we are perpetrating fundamental injustices against those who lack the voice and ability to speak for themselves. Cultural relativism, despite its pretenses to the contrary, involves making judgments and, in the process, ends up condoning abuses perpetrated against the voiceless and disenfranchised.

\section{Emphasis on the Group at the Expense of the Individual and the Misunderstanding of Self-Determination}

Unlike anthropologists, who often tend to emphasize the importance of groups, most universalists take the position that the locus of human rights is most properly situated in an individual. Universalists recognize an individual 
as the unit of cultural evolution and selection. They also recognize that rights of groups are best protected by attending first to individual rights. For example, the best way to protect the rights of any cultural group to practice their customs and religion is to guarantee freedom of religion and expression to all their members. That way, anybody wishing to practice may do so, while those wishing to abstain, for whatever reason, have their rights protected as well. In contrast, if one were to grant such a right to the group, the individuals who disagree with the views of the majority would have no recourse. History has shown over and over that groups and cultures show a proclivity toward the exploitation of individuals or entire classes of individuals, such as women or children, and that without the proper legal constraints, groups will abuse their powers in a manner that guts the very idea of human rights.

In contrast, proponents of cultural relativism adopt a group-centered view of the world and disregard the fact that many societies place several restrictions on many of their members and especially their women. Many proposals calling for the establishment of group rights are based on research that does not adequately reflect such intracultural diversity. What may be advantageous for the group, or for religious or political elites within that group, may or may not be in the interests of individuals belonging to that group or even in the interests of the entire group. Far too many ethnographies provide little or no information about intracultural diversity and treat women and other disadvantaged groups as essentially marginal and irrelevant by failing to reflect their opinions, beliefs, and the degree of their acquiescence to the dominant cultural practices (Geertz 1968).

The degree of individual freedom tends to vary with the degree of socioeconomic organization of a culture (A. Johnson and Earle 1987). Individuals living in nonstratified communitarian societies have a relatively high degree of independence from the group. Although the rights of individuals in these societies may be contingent on gender, age, or kinship status of the individual, the informal structure of these societies allows individuals to negotiate a reasonable degree of independence and thus to escape most of the group-sanctioned abuses (Lee 1979, 1984; Lee and DeVore 1968; Flanagan 1989). The more complex and more stratified the society, the more pronounced are differences between the interests of the group and the individuals (A. Johnson and Earle 1987). For example, the more stratified the society, the less freedom is afforded to women. Many stratified societies practice hypergyny, i.e., the families try to ensure that their daughters marry up into families with a higher standing than their own (Edgerton 1992). To make their daughters marketable, families watch them vigilantly to ensure their virginity, through physical seclusion of girls, whether by veiling or purdah, through the practice of foot binding, female genital mutilation, and other physical constraints that are designed to decrease women's erotic desires and insure their fidelity to a future husband (Kerr 1993; Mathieu 1989, 1990; Patel 1986). Such gender-based exploitation serves the purpose of families, but it does so at a heavy cost to girls and women, who lose their freedom and whose quality of life is diminished drastically. 
Yet most relativists subscribe to the view that all groups of people have a right to create their own form of government and culture, no matter how repressive or reprehensible it may be either to outsiders or to the minority of individuals living within that culture. According to this interpretation, selfdetermination means something quite different from the legal definition of self-determination (which basically states that no state may impose a cultural or political system on people living beyond its borders) (Higgins 1994). Furthermore, this interpretation of self-determination leads to the conclusion that individuals living in oppressive and inhumane regimes should be left at the mercy of these regimes and cultures. In this vein, many relativists have argued that even the most brutal customs which are grounded in cultural or religious prescriptions should be exempt from the prohibition of torture or other human rights standards. But history shows that ethical and moral standards can be and have been raised throughout the world due to the adoption of a universal approach to human rights. Abolition of slavery is one example of such global elevation of human dignity (Donnelly 1989). Although slavery was accepted by virtually all traditional religions and numerous cultures, it is now generally agreed that slavery is not compatible with the inherent dignity of the human being, regardless of religious and other cultural justifications of the practice. Therefore, it is not unreasonable to argue that in order to ensure basic dignity for all individuals, cultural-relativistic claims should at least be subject to the minimum standards of universal human rights law.

\section{The Abdication of Ethical Responsibility; Self-Serving Uses of Cultural Relativism; Unsustainability}

The self-imposed straitjacket of absolute respect for all forms of cultural behavior precludes relativists from making cross-cultural judgments and from engaging in meaningful comparisons. Many governments, especially those of the Third World countries, have realized the political usefulness of relativism and have erected upon it the position that governments are free to suppress and suspend the human rights of their citizens in the name of cultural sovereignty. In recent years, several Third World countries have challenged the very principle of the universality of international law (Cook 1990; Hannum 1990). The problem with their challenge is that they are mostly, if not exclusively, self-serving. Those who defend culturally sanctioned violence against women do so, not in order to uphold abstract ancient cultural principles, but typically to advance their own self-interest, be that economic, social, or political. Their claims that universal human rights are nothing more than a Western importation designed to perpetuate Western imperialism and to impair the economic and cultural development of Third World cultures are thinly veiled attempts to strengthen their own power base. Religious fundamentalists such as Kosami routinely denounce the excessive individualism of universal human rights and object to the imposition of Western values, which they claim are embedded in universal human rights law. Such self-serving rhetoric was also embraced by most of the former governments of the Soviet 
bloc countries, and it was only abandoned after the fall of Communism. Even though the Soviet bloc governments ratified the vast majority of international human rights instruments, they continued to denounce the so-called capitalist nature of human rights law and insisted that the treatment of their own nationals was a purely domestic matter. They also argued that any grant of rights must be contingent upon an individual's performance of his or her duties to the society and that the needs of a community must always come before the rights of individuals. In spite of this rhetoric, the citizens of the Soviet bloc embraced the ideals of the Universal Declaration of Human Rights and other human rights instruments in their struggle against Communism. It was only after the fall of Communism that the cynical nature of the Communist rhetoric was fully exposed. Unfortunately, such rhetoric is still prevalent among many regimes particularly in Asia and Africa.

History has shown that it is unwise to accept at face value any official claims that the systematic discrimination or presence of cruel customs is part of the cultural heritage of a society. The only meaningful defense of abusive customs that would be consistent with the principles of human dignity and autonomy would be a bona fide showing that each subjugated and abused individual consented to such a practice and that such consent was knowing and informed. In practice, most individuals living in traditional and indigenous societies have few, if any, economic or other options and are incapable of giving an informed consent to harmful or brutalizing customs.

The growing conflicts between rights of individuals and group-sanctioned violence are only likely to intensify in the near future. In particular, the impact of culture and tradition on the treatment of women must be carefully evaluated by analyzing who benefits from the tradition versus who bears the cost of the tradition and by looking at class and power distribution in the society, as well as the politics of the so-called traditions. International human rights norms offer a useful framework for resolving conflicts between women's rights and traditional customs that harm and dehumanize women. Universal human rights standards act as limits on the excesses of culture- and religion-based violence. They ensure that culture is not used as an excuse to limit and impair women's de jure and de facto rights. Ultimately, the rights of individuals and groups must be balanced by evaluating the nature and significance of cultural practices, their effects on the weakest members of the society, the degree to which the conflicting rights interfere with each other, the cumulative effects of potential restrictions on either's rights, and the proportionality of the restriction (Sullivan 1992). The extent to which women will be able to exercise their rights within various cultures and succeed in minimizing violence and gender-based inequalities will be ultimately linked to these women's abilities to share in the interpretation of their cultural traditions.

The assertion, often made by relativists, that indigenous women are indifferent to, or offended by, Western notions of human rights is factually erroneous. The criticism of feminism as nothing more than a Western imperialist ideology fails to explain the ever-growing women's movements across the 
globe (Cobbah 1987; Dwyer 1991; Kerr 1993; Legesse 1980; Peters and Wolper 1995). For example, African women have organized educational campaigns to combat the brutal sexual surgery of clitoridectomy. Many Muslim feminists are fighting against conservative Muslim clerics, such as Kosami, by recognizing that religious fundamentalism is nothing more than "patriarchal attitudes and cultural traditions disguised as religious norms" (Mernissi 1991:ix; see also Patel 1986; Dwyer 1991; Weaver 1994). As one prominent Moroccan feminist, Fatima Mernissi, sees it, true Islam allows for "dignity, democracy, and human rights." According to Mernissi, "if women's rights are a problem for some modern Muslim men, it is neither because of the Koran nor the Prophet, nor the Islamic tradition, but simply because those rights conflict with the interest of a male elite" (Mernissi 1991:ix). Peasant women in India have organized themselves to prevent dowry-related burning of young women (Jayawardena 1986). The Fourth World Conference of Women, which took place in September of 1995 in Beijing, was attended by large numbers of women from traditional societies. All those developments belie the relativists' view that universal human rights are excessively Western and not desired by nonWestern individuals. Many such non-Western individuals not only support and embrace the universal standards; they use them as a tool in the internal cultural dialogue that is ongoing in many societies today.

From a practical perspective, relativism is unsustainable in the modern world. Even the most remote indigenous groups have been substantially integrated into the global economy and are subject to ever-growing external influences (Cultural Survival 1993). It is precisely these peoples who desperately need the protection of their human rights, and ironically, it is often the dictators, the fundamentalists, and the multinational companies who chant the mantra of cultural relativism for their own benefit. By refusing to engage in the evaluation of other cultures and their practices, cultural relativists are unable to analyze the true nature of such politically motivated claims and are unwittingly lending a helping hand to those who benefit from resurrecting, appropriating, or inventing whatever customs they see fit.

\section{CONCLUSION}

Cultural relativism, in its various forms, has entered the debate about human rights and has been steadily gaining popularity among many groups and individuals. Perhaps this is so because some scholars believe that cultural relativism is the only alternative to the dangers of ethnocentrism and moral absolutism (Hatch 1983; Jarvie 1983). Or maybe this is due to its intuitive appeal to many politicians and activists who use it to advance their own agendas. Or perhaps because of the political expediency that cultural relativism offers to governments and those in power, the ideas of cultural relativism continue to expand well beyond academe. Whatever the reason, cultural relativism has the potential of undermining the modern human rights law developed during the last fifty years. In fact, some major international human rights treaties, such as 
the Convention on the Elimination of All Forms of Discrimination against Women, are being rewritten and amended to accommodate various cultural and religious differences in the name of cultural relativism, gutting in the process the whole idea that women deserve basic human rights protections (Cook 1990).

Contrary to the assertions and fears of relativists, human rights universalism does not take away decision-making powers from individual cultures, nor does it have demoralizing and homogenizing effects. Nor is there any evidence to show that universalism is merely a form of uncritical ethnocentric Western conspiracy designed to undermine non-Western cultures. It may well be that universal human rights ideals were first recognized and developed in the West, but that does not mean such ideals are alien to non-Western cultures. Similarly, while the development of international human rights law during the last forty years was primarily spearheaded by Western nations, it does not mean that the resulting international human rights regime is ethnocentric and unjust.

The main objective of the existing universal human rights regime is not to impose a jacket of arbitrary and homogenizing uniformity among diverse cultural traditions. Instead, the goal of universalism is to create a floor below which no society can stoop in the treatment of its citizens. Conversely, universalism has never aspired to establish an upper ceiling of what the ideal or maximum level of human rights should be, leaving such improvements and enhancements to each individual culture in accordance with its resources and abilities. All major international instruments and treaties, such as the United Nations Charter, the Universal Declaration of Human Rights, together with its two binding Covenants, and all major international conventions such as the convention against torture, slavery, and genocide, are attempts at universalizing only the minimum standards of treatment of all individuals.

Due to a minimalist approach to standard setting, modern international human rights law is fully compatible with cultural diversity and moral diversity found around the world. Under universalism, each state and culture retains sovereign power over its own cultural development albeit within the limits delineated by international law. Although the limitations imposed by international human law are minimal, they provide important protections for individuals who would otherwise be entirely at the mercy of the state or the group in power. These protections include such basic rights as the right to bodily integrity; the right to be free from torture and physical and psychological abuse; the right to be free from arbitrary courts, imprisonment, and police coercion; the right to be free from slavery and genocide; the right to free speech; and the right to choose to be associated with, or be free of, any religion, culture, ethnicity, and language.

Although human rights universalism has its flaws, universalism often provides the only avenue available to individuals in their intracultural struggle for fairness, justice, and equality. Consequently, the abandonment of universalism in favor of cultural relativism would have profound implications for those brutalized in the name of culture or religion. Even the critics of human rights universalism admit that the international sanction provided by universalism is 
conducive to the preservation of internal dialogue within many totalitarian societies and thus provides the needed leverage to improve the human rights situation within those countries (An-Na'im 1992).

The tension between the rights of groups to maintain their traditional culture and the rights of individuals to reject that culture, either in whole or in part, is only likely to increase in the future. We must strive therefore to develop criteria for balancing the needs of both by finding new ways in which universal ideals can be internalized and legitimized in various cultures. There are many as yet unanswered questions, such as how to determine which rights are more fundamental than others, which rights should be considered nonderogable, and which rights can be recognized as more culturally dependent. Is it possible to develop an international consensus as to the criteria which could be used to critically evaluate cultural customs and to judge them? How shall we engage in a comparison of cultures? How can we most effectively legitimize the claim that certain ethical and moral considerations are absolute in a sense that they should not be violated or deferred under any circumstances? Such answers have yet to be completely articulated, but in order to achieve further progress in this area, it is necessary to abandon the uncritical pluralism postulated by cultural relativism. Indeed, anthropologists are in the unique position to promote the observance of human rights among the societies they work in by researching the congruence between local traditions and the universal norms. In all likelihood, the observance of human rights in all societies will be significantly improved if those rights are perceived as legitimate and fitting into the local tradition (An-Na'im 1992).

There exist genuine differences among cultures, and not all such differences can easily be reconciled. The universal human rights law represents an attempt to strike a proper balance between the rights of each individual culture to create its own moral and ethical norms and the needs of individuals to be protected against arbitrary and brutal customs and cultural practices. As such, human rights universalism is worthy of protection against the cultural relativistic assault. Despite all its flaws, human rights universalism still offers the best hope of dignified life to the world's population.

\section{REFERENCES CITED}

American Anthropological Association Executive Board (AAA), 1947, Statement on Human Rights (submitted to the United Nations Commission on Human Rights). American Anthropologist (n.s.) 49(4):539-43.

An-Na'im, A.A., ed., 1992, Human Rights in Cross-Cultural Perspectives: A Quest for Consensus. Philadelphia: University of Pennsylvania Press.

Barkow, J.H., L. Cosmides, and J. Tooby, eds., 1992, Adapted Mind: Evolutionary Psychology and the Generation of Culture. New York: Oxford University Press.

Benedict, R., 1934, Patterns of Culture. Boston: Houghton Mifflin.

Bhatia, S., 1996, Algerian Girls Slain If They Attend School. Atlanta Journal/Atlanta Constitution, 18 February, p. C11.

Bidney, D., 1968, Cultural Relativism. Pp. 543-47 in International Encyclopedia of 
the Social Sciences, vol. 3 (ed. by D.L. Sills). New York: Macmillan.

Boas, F., 1894, Human Faculty as Determined by Race. Proceedings of the American Association for the Advancement of Science 43:301-27.

Boas, F., 1901, The Mind of Primitive Man. Journal of American Folklore 14:1-11.

Boserup, E., 1965, The Conditions of Agricultural Growth. Chicago: Aldine de Gruyter.

Boulware-Miller, K., 1985, Female Circumcision: Challenges to the Practices as a Human Rights Violation. Harvard Women's Law Journal 8:155-77.

Boyd, R., and P. Richerson, 1985, Culture and the Evolutionary Process. Chicago: University of Chicago Press.

Buergenthal, T., 1988, International Human Rights in a Nutshell. St. Paul, Minn.: West Publishing Company.

Butegwa, F., 1993, The Challenge of Promoting Women's Rights in African Countries. Pp. $40-42$ in Ours by Right: Women's Rights as Human Rights (ed. by J. Kerr). London: Zed Books.

Cavalli-Sforza, L.L., and M.W. Feldman, 1981, Culture Transmission and Evolution: A Quantitative Approach. Princeton, N.J.: Princeton University Press.

Clifford, J., and G.E. Marcus, eds., 1986, Writing Culture: The Poetics and Politics of Ethnography. Berkeley: University of California Press.

Cobbah, J., 1987, African Values and the Human Rights Debate: An African Perspective. Human Rights Quarterly 9:309-31.

Cohen, M.N., 1977, The Food Crisis in Prehistory: Overpopulation and the Origins of Agriculture. New Haven, Conn.: Yale University Press.

Cook, R.J., 1990, Reservations to the Convention on the Elimination of All Forms of Discrimination against Women. Virginia Journal of International Law 30:643-709.

Coomaraswamy, R., 1994, To Bellow Like a Cow: Women, Ethnicity and the Discourse of Rights. Pp. 39-57 in Human Rights of Women (ed. by R.J. Cook). Philadelphia: University of Pennsylvania Press.

Cultural Survival, 1993, State of the Peoples: A Global Human Rights Report on Societies in Danger (M.S. Miller, project director). Boston: Beacon Press.

Daly, M., and M. Wilson, 1983, Sex, Evolution and Behavior. 2nd ed. Boston: Willard Grant.

Daly, M., and M. Wilson, 1988, Homicide. New York: Aldine de Gruyter.

Donnelly, J., 1989, Universal Human Rights in Theory and Practice. Ithaca, N.Y.: Cornell University Press.

Donnelly, J., 1990, Human Rights, Individual Rights and Collective Rights. Pp. 39-62 in Human Rights in a Pluralist World: Individuals and Collectivities (ed. by J. Berting, P.R. Baehr, J.H. Burger, C. Flinterman, B. de Klerk, R. Kroes, C.A. van Minnen, and K. van der Wal). Westport, Conn.: Meckler.

Downing, T.E., 1988, Human Rights Research: The Challenge for Anthropologists. Pp. 9-20 in Human Rights and Anthropology. Cultural Survival Report 24. Cambridge, Mass.: Cultural Survival.

Downing, T.E., and G. Kushner, 1988, Anthropology and Human Rights: A Selected Biography. Pp. 125-93 in Human Rights and Anthropology. Cultural Survival Report 24. Cambridge, Mass.: Cultural Survival.

Dworkin, R., 1978, Taking Rights Seriously. Cambridge, Mass.: Harvard University Press.

Dwyer, K., 1991, Arab Voices: The Human Rights Debate in the Middle East. Berkeley: University of California Press. 
Edgerton, R.B., 1992, Sick Societies: Challenging the Myth of Primitive Harmony. New York: The Free Press.

Etienne, M., and E. Leacock, eds., 1980, Women and Colonization. New York: Praeger.

Fernandez, J.W., 1990, Tolerance in a Repugnant World and Other Dilemmas in the Cultural Relativism of Melville J. Herskovits. Ethos 18(2):140-64.

Flanagan, J.G., 1989, Hierarchy in Simple "Egalitarian" Societies. Annual Review of Anthropology 18:245-66.

Flannery, K., 1972, The Cultural Evolution of Civilizations. Annual Review of Ecology and Systematics 3:399-426.

Geertz, C., 1968, Islam Observed. Chicago: University of Chicago Press.

Geertz, C., 1973, Interpretation of Cultures. New York: Basic Books.

Geertz, C., 1984, Distinguished Lecture: Anti Anti-Relativism. American Anthropologist 86:263-78.

Gellner, E., 1985, Relativism and Social Sciences. New York: Cambridge University Press.

Gordon, D.A., 1993, The Unhappy Relationship of Feminism and Postmodernism in Anthropology. Anthropological Quarterly 66(3):109-17.

Hannum, H., 1990, Autonomy, Sovereignty, and Self-Determination: The Accom modation of Conflicting Rights. Philadelphia: University of Pennsylvania Press.

Harris, M., 1971, Culture, Man, and Nature: An Introduction to Cultural Anthropology. New York: Crowell.

Harris, M., 1977, Cannibals and Kings: The Origins of Cultures. New York: Random House.

Harris, M., 1985, Good to Eat: Riddles of Food and Culture. New York: Simon and Schuster.

Hastrup, K., and P. Elsass, 1990, Anthropological Advocacy: A Contradiction in Terms? Current Anthropology 31(3):301-11.

Hatch, E.J., 1973, Theories of Man and Culture. New York: Columbia University Press.

Hatch, E., 1983, Culture and Morality: The Relativity of Values in Anthropology. New York: Columbia University Press.

Herskovits, M.J., 1958, Some Further Comments on Cultural Relativism. American Anthropologist 60:266-73.

Herskovits, M.J., 1973, Cultural Relativism: Perspectives in Cultural Pluralism. New York: Vintage Books.

Higgins, R., 1994, Problems and Process: International Law and How to Use It. New York: Oxford University Press.

Jameson, F., 1991, Postmodernism, or the Cultural Logic of Late Capitalism. Minneapolis: University of Minnesota Press.

Jarvie, I.C., 1983, Rationality and Relativism. British Journal of Sociology 34(1):44-60. Jayawardena, K., 1986, Feminism and Nationalism in the Third World. London: Zed Books.

Johnson, A., 1975, Time Allocation in a Machiguenga Community. Ethnology 14:301-10.

Johnson, A., ed., 1987, Cross-Cultural Studies in Time Allocation. New Haven, Conn.: Human Relations Area Files.

Johnson, A., and T. Earle, 1987, The Evolution of the Human Society: From Foraging Group to Agrarian State. Stanford, Calif.: Stanford University Press. 
Johnson, O., 1978, Domestic Organization and Interpersonal Relations among the Machiguenga Indians of the Peruvian Amazon. Ph.D. diss., Columbia University.

Johnson, P., 1981, When Dying Is Better Than Living. Ethnology 20(4):325-34.

Joint Consultative Group on Policy, 1991, Women and Structural Adjustment. New York: United Nations Population Fund.

Kaplan, H., K. Hill, and A.M. Hurtado, 1990, Risk, Foraging, and Food Sharing among the Ache. Pp. 107-43 in Risk and Uncertainty in Tribal and Peasant Economies (ed. by E. Cashdan). Boulder, Colo.: Westview Press.

Kerr, J., ed., 1993, Ours by Right: Women's Rights as Human Rights. Ottawa: Zed Books.

Kluckhohn, C., 1955, Ethical Relativity: Sic et Non. Journal of Philosophy 52:663-77.

Kolakowski, L., 1978, Main Currents of Marxism. 3 vols. Oxford: Clarendon Press.

Kroeber, A.L., 1935, History and Science in Anthropology. American Anthropologist 37:539-69.

Kroeber, A.L., 1948, Anthropology: Culture Patterns and Processes. New York: Harcourt Brace Jovanovich.

Kroeber, A.L., 1952, The Nature of Culture. Chicago: Chicago University Press.

Leacock, E., 1978, Women's Status in Egalitarian Society: Implications for Social Evolution. Current Anthropology 19(2):247-75.

Lee, R., 1979, The !Kung San: Men, Women, and Work in a Foraging Society. Cambridge, Eng.: Cambridge University Press.

Lee, R., 1984, The Dobe !Kung. New York: Holt, Rhinehart and Winston.

Lee, R., and I. DeVore, eds., 1968, Man the Hunter. Chicago: Aldine.

Legesse, A., 1980, Human Rights in African Political Culture. Pp. 123-38 in The Moral Imperatives of Human Rights: A World Survey (ed. by K.W. Thompson). Lanham, Md.: University Press of America.

Marcus, G.E., and M.M.J. Fischer, 1986, Anthropology as Cultural Critique: An Experimental Moment in the Human Sciences. Chicago: University of Chicago Press.

Mathieu, N-C., 1989, When Yielding Is Not Consenting, Part 1. Pp. 3-49 in Feminist Issues (Fall).

Mathieu, N-C., 1990, When Yielding Is Not Consenting, Part 2. Pp. 51-90 in Feminist Issues (Spring).

Mead, M., 1928, Coming of Age in Samoa. New York: Morrow.

Mead, M., 1963, Socialization and Enculturation. Current Anthropology 4:184-88.

Mernissi, F., 1991, The Veil and the Male Elite: A Feminist Interpretation of Women's Rights in Islam (trans. by M.J. Lakeland). Reading, Mass.: Addison-Wesley Publishing Company.

Mill, J.S., 1952[1859], On Liberty. Pp. 261-323 in Great Books of the Western World, vol. 43 (ed. by R.M. Hutchins). Chicago: Encyclopaedia Britannica, Inc.

Moore, H., 1988, Feminism and Anthropology. Minneapolis: University of Minnesota Press.

Nussbaum, M.C., 1993, Non-Relative Virtues: An Aristotelian Approach. Pp. 242-69 in The Quality of Life (ed. by M.C. Nussbaum and A. Sen). New York: Oxford University Press.

Nussbaum, M.C., 1995, Human Capabilities, Female Human Being. Pp. 61-104 in Women, Culture and Development: A Study of Human Capabilities (ed. by M.C. Nussbaum and J. Glover). New York: Oxford University Press.

Nussbaum, M.C., and A. Sen, 1989, Internal Criticism and Indian Rationalist Traditions. Pp. 299-325 in Relativism: Interpretation and Confrontation (ed. by M. Krausz). 
Notre Dame, Ind.: Notre Dame University Press.

Patel, R., 1986, Pakistan: Muslim Women and the Law. Pp. 110-15 in Empowerment and the Law: Strategies of Third World Women (ed. by M. Schuler). New York: OEF International.

Peters, J., and A. Wolper, eds., 1995, Women's Rights, Human Rights: International Feminist Perspectives. New York: Routledge.

Pinker, S., 1994, The Language Instinct. New York: William Morrow and Company.

Pollis, A., and P. Schwab, 1979, Human Rights: A Western Concept with Limited Applicability. Pp. 1-18 in Human Rights: Cultural and Ideological Perspectives (ed. by A. Pollis and P. Schwab). New York: Praeger.

Rawls, J., 1971, Theory of Justice. Oxford: Clarendon Press.

Redfield, R., 1953, The Primitive World and Its Transformations. Ithaca, N.Y.: Cornell University Press.

Redfield, R., 1957, The Universally Human and Culturally Variable. Journal of General Education 10:150-60.

Rosaldo, R., 1984, Grief and a Headhunter's Rage: On the Cultural Force of Emotions. Pp. 178-95 in Text, Play, and Story: The Construction and Reconstruction of Self and Society (ed. by E.M. Bruner). Proceedings of the American Ethnological Society 1983. Prospect Heights, Ill.: Waveland Press.

Sahlins, M.D., 1960, Evolution: Specific and General. Pp. 12-44 in Evolution and Culture (ed. by M.D. Sahlins and E.R. Service). Ann Arbor: University of Michigan Press.

Sahlins, M.D., 1968, Tribesman. Engelwood Cliffs, N.J.: Prentice Hall.

Sahlins, M.D., 1972, Stone Age Economics. New York: Aldine.

Sanders, W.T., J. Parsons, and R. Santley, 1979, The Basin of Mexico: Ecological Processes in the Evolution of Civilization. New York: Academic Press.

Sen, A., 1990, More Than 100 Million Women Are Missing. New York Review of Books, 20 December, pp. 60-66.

Sen, A., 1993, Capability and Well Being. Pp. 30-61 in The Quality of Life (ed. by M.C. Nussbaum and A. Sen). New York: Oxford University Press.

Service, E.R., 1975, Origins of the State and Civilization: The Process of Cultural Evolution. New York: W.W. Norton and Company.

Spencer, H., 1904, Progress: Its Law and Cause. Reprinted in Essays, Scientific, Political and Speculative (by H. Spencer). New York: Appleton.

Spiro, M.E., 1984, Some Reflections on Cultural Determinism and Relativism with Special Reference to Emotion and Reason. Pp. 323-46 in Culture Theory: Essays on Mind, Self and Emotion (ed. by R.A. Shweder and R.A. LeVine). New York: Cambridge University Press.

Spiro, M.E., 1986, Cultural Relativism and the Future of Anthropology. Cultural Anthropology 1:259-86.

Steward, J.H., 1948, Comments on the Statement on Human Rights. American Anthropologist 50:351-52.

Steward, J.H., 1955, Theory of Culture Change: The Methodology of Multilinear Evolution. Urbana: University of Illinois Press.

Sullivan, D.J., 1992, Gender Equality and Religious Freedom: Toward a Framework for Conflict Resolution. New York University Journal of International Law and Politics 24:795.

Sullivan, D.J., 1994, Women's Human Rights and the 1993 World Conference on Human Rights. American Journal of International Law 88(1):152-67. 
Tooby, J., and L. Cosmides, 1990, On the Universality of Human Nature and the Uniqueness of the Individual. Journal of Personality 58:17-67.

United Nations Human Rights Commission, 1989, Consideration of Report Submitted by State Parties under Article 40 of the Covenant. Second Periodic Report 1985. U.N. Doc. CCPR/C/37/Add. 13.

Weaver, M.A., 1994, Letter from Bangladesh: A Fugitive from Injustice. New Yorker, 12 September, pp. 48-60.

Weinreb, L.L., 1987, Natural Law and Justice. Cambridge, Mass.: Harvard University Press. 